\title{
Language Contact and Morphosyntactic Complexity: Evidence from German
}

\author{
Péter Maitz \\ University of Augsburg \\ Attila Németh \\ University of Pannonia
}

\begin{abstract}
The article focuses on the hypothesis that the structural complexity of languages is variable and historically changeable. By means of a quantitative statistical analysis of naturalistic corpus data, the question is raised as to what role language contact and adult second language acquisition play in the simplification and complexification of language varieties. The results confirm that there is a significant correlation between intensity of contact and linguistic complexity, while at the same time showing that there is a need to consider other social factors, and, in particular, the attitude of a speech community toward linguistic norms.*
\end{abstract}

\section{Introduction.}

In the past decade, there has been a lively discussion within linguistics about the notion of linguistic complexity. This discussion is based on the anti-Cartesian assumption that linguistic complexity is variable. First, all languages are by no means equally complex (as was assumed in modern linguistics for some time), and second, the degree of linguistic complexity can change over time. ${ }^{1}$ Relevant research focuses mainly on three questions: 1) What is linguistic complexity? How can it be defined? 2)

\footnotetext{
* We would like to thank Stephan Elspaß, Werner König, Martin Durrell, Peter Trudgill, and the two anonymous referees of our paper for their valuable comments and suggestions. Of course, any remaining shortcomings are entirely our own responsibility.

${ }^{1}$ See, for example, Hockett 1958:180f. Sampson (2009) reflects on the history and background of the equi-complexity axiom. Shosted (2006), among others, empirically falsifies the hypothesis that a lesser degree of complexity in one linguistic component is equalized by the greater complexity of another.
} 
How can linguistic complexity be measured? 3) What internal and/or external factors influence the complexity of a language; that is, under what circumstances does simplification or complexification take place?

Relevant research is being carried out in particular within the fields of linguistic typology, second language acquisition, and contact linguistics, and this has produced pertinent theoretical, methodological, and empirical results. Seminal publications include Kusters 2003, Dahl 2004, Miestamo et al. 2008, Sampson et al. 2009, McWhorter 2011, Trudgill 2011a, Kortmann \& Szmrecsanyi 2012, and papers of the Surrey Morphology Group. ${ }^{2}$ In the framework of the present paper, we cannot give a systematic overview on the state of the art. Szmrecsanyi \& Kortmann (2012) have recently provided an instructive survey of current research trends and results, from which it is clear. For our own purposes we want to emphasize only the fact that relevant empirical-quantitative research in the Germanic languages has focused up to now principally on varieties of English (for example, Kortmann \& Szmrecsanyi 2012). Studies of other Germanic languages have mainly concentrated on (written) standard varieties (for example, Kusters 2003, McWhorter 2004, Dammel \& Kürschner 2008). By contrast, this paper aims at testing some central assumptions in research by analyzing data from different standard and nonstandard varieties of German as well as discussing some basic methodological questions and problems.

In section 2, we introduce our background assumptions and research hypotheses. Section 3 deals with the methodology and data used in our quantitative analyses, with the results being presented in section 4 . In section 5, these results are discussed, open questions are posed, and some perspectives in research are pointed out.

\section{Background Assumptions and Research Hypotheses.}

As mentioned above, the central background assumption of recent research concerning the issue of linguistic complexity ensues from questioning the equi-complexity axiom. Accordingly, our first underlying assumption is as follows:

\footnotetext{
${ }^{2}$ See http://www.surrey.ac.uk/englishandlanguages/research/smg/publications/ index.htm for lists of recent publications.
} 
(1) The degree of structural complexity of languages is variable and may change over time.

The definition and explanation of linguistic complexity depend to a great extent on one's theoretical approach to language. As our analyses are based on a sociolinguistic approach, our second underlying assumption is as follows:

(2) As a result of the social embeddedness of language, language variation and language change are (also) influenced by social factors/structures.

1 and 2 lead to the following assumption:

(3) The degree of complexity of a language and its change are (also) influenced by social factors/structures.

One of the most important and most challenging questions discussed in the context of linguistic complexity is the question of what social factors/structures influence linguistic complexity and its change. The following factors, in particular, are currently under discussion: 1) language contact, 2) density of the social network, and 3) size of the speech community (see, for example, Trudgill 2009, 2010, 2011a; Kortmann \& Szmrecsanyi 2009, Sinnemäki 2009). In particular, the role of language contact has recently been the center of attention in research, and we shall, therefore, also focus on it here.

Language contact can have a variety of consequences. For instance, it can lead to additive complexification of a language through transfer (see Trudgill 2011a:26-32) or to Sprachbund effects. We assume that language contact can also lead to broad typological changes and, in particular, to structural simplification. The cause of such contact-induced simplification is adult second language acquisition, which in most cases does not lead to native proficiency attained through first language acquisition. To a large extent, this is due to biological factors (see Lenneberg 1967). Trudgill (2001:372) claims

Just as complexity increases through time, and survives as the result of the amazing language-learning abilities of the human child, so complexity disappears as a result of the lousy language-learning abilities of 
the human adult. Adult language contact means adult language learning; and adult language learning means simplification.

Such simplification resulting from second language acquisition can be interpreted as pidginization, and these processes can lead to the emergence of pidgins in specific socioeconomic contexts, although this is a rare occurrence (see Trudgill 2009). The role such contact-induced simplification can play in language change-even beyond the emergence of pidgins - was identified earlier in some contexts, for example, in the history of English, in the transition from Old to Middle English (see Milroy 1992), or in the typological developments of Norwegian in the Hanseatic period (see Jahr 2001, Braunmüller 2004). However, this approach has not yet been applied to the broad, typologically relevant morphosyntactic developments of German, although Hinrichs (2004, 2009) and Wegener (2007:51f) have repeatedly pointed out that language contact might have played a significant role in a number of morphosyntactic simplifications in Standard German.

In what follows, when analyzing the influence of language contact on the complexity of different varieties of German, we are referring to the role of adult second language learning and the resultant simplification. Languages or varieties likely to be influenced by adult second language acquisition (compared with other languages or varieties) are referred to as high-contact languages or varieties. Languages or varieties on which adult second language acquisition has little or no influence are referred to as low-contact varieties.

Our hypotheses concerning the correlation between language contact and linguistic complexity are the following:

(4) HYP1: High-contact languages or varieties tend to undergo structural simplification.

HYP2: Low-contact languages or varieties tend to retain or increase structural complexity. ${ }^{3}$

\footnotetext{
${ }^{3}$ The question why complexity is not only retained but can also increase in lowcontact varieties cannot be discussed in this paper. This issue is dealt with, in particular, by Trudgill $(2009,2011)$.
} 
Like Szmrecsanyi \& Kortmann (2012:8), we also have our doubts as to whether it is realistic to assess the global complexity of a language. However, measuring the local complexity of certain linguistic subdomains seems to be feasible. Our analyses deal with morphosyntactic complexity and are methodologically based on the Freiburg approach (see Kortmann \& Szmrecsanyi 2009, Szmrecsanyi \& Kortmann 2012). In the following section, we present some of the major aspects of this approach relevant for our study, that is, the definition of linguistic complexity, the methodology for measuring or quantifying it, and the data that our analyses are based on.

\section{Methodology.}

\subsection{Preliminaries.}

The definition of complexity is still one of the leading theoretical desiderata in the relevant research (see, for example, Kusters 2008, Miestamo 2008, Szmrecsanyi \& Kortmann 2012). At present, several different definitions and criteria have been discussed and used in empirical analyses. This results in a number of methodological problems, as different definitions inevitably lead to different methodological approaches to complexity and often even to different empirical research findings. There are generally two perspectives on linguistic complexity (see Kusters 2008:4-12): ABSOLUTE COMPLEXITY (theory-oriented/objective) and RELATIVE COMPLEXITY (user-oriented/subjective). These two perspectives give rise to at least four potential levels of complexity (see Trudgill 2011a, Szmrecsanyi \& Kortmann 2012:10-12):

\section{(5) Level 1: Absolute-Quantitative Complexity}

The structural elaboration of the morphosyntactic inventory of a given variety can be measured by the number of grammatical categories and/or the frequency of overt synthetic or analytic grammatical markers.

\section{Level 2: Redundancy-Induced Complexity}

Structural elaboration does not lead to a communicative bonus, as, for example, in the case of the explicit grammatical marking of gender. 
Level 3: Irregularity-Induced Complexity

Structural elaboration can be measured by the frequency of occurrence of irregular inflectional morphemes.

\section{Level 4: L2 Acquisition Complexity}

The (individual) degree of difficulty in second language acquisition is viewed as a subjective category.

According to Kortmann \& Szmrecsanyi 2012, levels 2 and 3 can be located between the absolute-quantitative and the relative user-oriented complexity because redundancy and irregularity can be evaluated differently, both theoretically and perceptively. In contrast, for Siegel (2012: 35-36) complexity involves a combination of absolute and relative complexity. He differentiates between COMPONENTIAL (that is, the number of marked grammatical distinctions and morphemes) and STRUCTURAL complexity (that is, semantic transparency, regularity, and perceptual salience). According to Siegel 2012:39, because of their perceptual salience, free (analytic) grammatical morphemes are learned first and in this sense can be seen as less complex than synthetic morphemes.

For reasons of comparability, as mentioned above, we follow the Freiburg approach, which marries different notions of complexity and methodologies (see Kortmann \& Szmrecsanyi 2004, 2009, 2012 inspired, among others, by Greenberg's 1960 quantitative method). Accordingly, we focus on the assessment of frequency-based morphosyntactic complexity in three different types of varieties: traditional low-contact L1 varieties, high-contact L1 varieties, and L2 varieties. These types of varieties are analyzed and compared on four levels, as shown in 6.

(6) a. SYNTHETICITY: the total frequency of bound grammatical morphemes per sample;

b. ANALYTICITY: the total frequency of free grammatical morphemes;

c. GRAMMATICITY: the sum of data for $6 a$ and $6 \mathrm{~b}$, that is, the entire amount of grammatical substance; 
d. IRREGULARITY: the frequency of occurrence of all irregular morphological markers, which - in contrast to regular forms require a more substantial learning effort and have a tendency to be overgeneralized, that is, regularized, in the course of adult L2 acquisition.

The factors in 6 are of considerable importance for measuring the differences in complexity between individual varieties under the assumption that different sociolinguistic constellations, which are typical of the varieties mentioned above, correlate with different degrees of complexity, as has been argued by Trudgill (for example, 2001). With regard to high-contact L2 varieties, we expect a lower degree of grammaticity and a higher degree of transparency (that is, fewer irregular grammatical morphemes) as a consequence of simplification due to adult language contact and second language acquisition.

\subsection{Data.}

In order to test our hypotheses empirically, three types of varieties (and four spoken varieties in total) of German were analyzed. The corpus consists of three subcorpora of authentic spoken varieties (for text samples, see the appendix). The first subcorpus originates from spoken Standard German, hereafter HCSG (high-contact Standard German). It is inherently high-contact in nature, as it is one of the major standard language varieties in Europe "which are the result in part of simplification resulting from dialect contact" (Trudgill 2011b:238). At the same time, it has long been permanently exposed to significant influence of contact with other languages/varieties. First, HCSG was for a long time the lingua franca in Central and Eastern Europe. Second, millions of people immigrated to Germany to work there, especially after the Second World War (but also in the years before).

We thus assume that HCSG has been acquired by millions of adults as an L2 for longer periods, and therefore stronger influence of adult second language acquisition can be expected. This variety is based on and influenced by its written counterpart with regard to numerous morphosyntactic characteristics. It shows, however, a large number of systematic differences resulting from primary features of conceptual orality (see Fiehler 2009). What develops within the norm of usage of this variety is a mixture of morphological features that can also be found 
in written Standard German, and of features that typically disappear in spoken language (for example, the systematic elimination of inflectional 1 st person singular affixes on verbs and of inflectional case markers, the elimination of the subject pronoun, etc.).

The second subcorpus originates from two high-contact varieties of German, hereafter referred to as PC (Pidgin/Creole German): Kiche Duits, or "kitchen German", also known as Namibian Black German, and Unserdeutsch (Rabaul Creole German). Black Namibian German developed in the former German colony in Namibia (1884-1914). This L2 variety can be situated between a group-based pidgin variety used in a private and professional environment on the one hand, and individual learners' varieties on the other. It was acquired by both young and adult speakers through contact with German colonists (see Deumert 2003:577 and 2009:374-379). Some of the most important morphosyntactic characteristics of Black Namibian German include the missing case and gender marking of nouns, the overgeneralization of $-s$ as a plural marker, the lack of subject-verb agreement, and the past tense either zero-marked or expressed by the past participle alone (see Deumert 2009:394-400).

Unserdeutsch is the sole recorded example of a German-based creole that developed through creolization of a pidgin in Rabaul on the Gazelle Peninsula in Papua New Guinea. The German pidgin originated as a result of the need for communication between mixed race orphans, and German nurses and missionaries, who took care of them and taught them German at school. After the First World War, German was still taught at the missionary schools. The creolization of the children's pidgin resulted from the fact that they remained socially isolated after leaving the boarding school. A small group of interracial families emerged, with the second generation in the 1960s acquiring Unserdeutsch as their L1 (see Mühlhäusler 2001:246f). Volker (1989:154-172) points out prototypical morphosyntactic characteristics of Unserdeutsch, for example, the missing case inflection of (optional) definite and indefinite articles, the elimination of the distinction between the 1st and 2nd person singular on verbs without stem change (for example, anfangen 'to begin'), and the nonrealization of perfect auxiliary verbs, as in kitchen German.

The third subcorpus originates from Cimbrian (Cimbro/Zimbrisch), a traditional low-contact L1 variety of German, hereafter referred to as LCL1G (low-contact L1 German). LCL1G developed in the late Middle Ages; it consists of a number of German varieties that derive from 
Bavarian dialects and are spoken in North East Italy. Thousands of native speakers in the provinces of Veneto and Trentino in northern Italy used LCL1G in former centuries (see Rowley 1996:272ff). Today, we can see a strong decline of LCL1G. Apart from two mountain villages with few remaining speakers (Giazza und Toballe), LCL1G is nowadays only used in Luserna (see Bidese 2005:5-7).

Despite some contact-based influence from Romance, which can be seen in the development of LCL1G morphosyntax (see Kolmer 2010), this traditional L1 variety shows a large number of inflectional characteristics of older stages of German, as well as indigenous developments. A rich and differentiated inflection system and a high degree of allomorphy with numerous double and multiple forms are characteristic of this variety (see Schweizer 2008), which has developed in isolation. These are the features that are particularly relevant for the complexity criteria mentioned above. From our point of view, LCL1G has to be classified as a low-contact variety: Because of the geographic isolation of the communities and the limited communicative range of LCL1G dialects it has not been acquired as a second language by native speakers of Italian. For this reason, no influence from adult second language acquisition is to be expected.

In order to compare the morphosyntax of these varieties, we created three subcorpora, each containing 3,000 randomly chosen words. The subcorpus of each variety consisted of three subsamples, 1,000 tokens each, which enabled us to eliminate statistical irregularities. For each variety, we analyzed comparable discourses in order to ensure maximum comparability of the data and to avoid potential variation in complexity due to different social contexts and text types. We mainly analyzed narrative discourses, including descriptions of past events or stories. The analyzed discourse fragments of Black Namibian German and Unserdeutsch were taken from Deumert 2003, 2009 and from the Unserdeutsch database of Cologne University. ${ }^{4}$ The LCL1G data were provided by the community of Giazza, and collected and transcribed by Schweizer (1939).

The HCSG data were taken from the Forschungs- und Lehrkorpus Gesprochenes Deutsch/Research and Teaching Corpus of Spoken German (FOLK, Datenbank für Gesprochenes Deutsch/Database of

\footnotetext{
${ }^{4}$ http://www.uni-koeln.de/gbs/, accessed on November 13, 2013.
} 
Spoken German). HCSG shows considerable variation depending on area, education, register, and the individual linguistic repertoire of the speakers. We therefore had to make sure to use data from the same homogenous social context. Our data consist of conversations among the medical staff during shift changes at a hospital, recorded in the Rhenish Franconian area (western-central Germany).

To calculate the frequency-based grammatical complexity of the varieties based on these data, we analyzed every subcorpus using the four morphosyntactic complexity metrics discussed in section 3.1. For all varieties, the frequency values were calculated for 1) all free grammatical morphemes (analyticity), 2) all bound grammatical morphemes (syntheticity), 3) the sum of all free and bound grammatical morphemes (grammaticity), and 4) all irregular morphological markers (irregularity). The statistical significance of the differences between the mean values for the varieties was tested by one-way ANOVA. The following section shows the results of the statistical analysis according to the four factors relevant to our hypotheses.

\section{Results.}

\subsection{Syntheticity.}

The occurrence of the following synthetic inflectional markers was calculated for all varieties in the corpora analyzed: 1) Case and number markers on nouns, pronouns, and articles. For example, HCSG in den Bein-e-n 'in one's legs' was counted as two instances of synthetic marking: $-e$ - as a plural marker and $-n$ as a dative marker; PC deine Vater 'your father', eine Mannenzimmer 'a men's room' were each counted as one instance of synthetic marking. Zero markers as well as stem modifications were not included; 2) Number and gender markers, and comparative forms of adjectives, for example, HCSG wieder lauter geworden 'became louder again' or so bekanntes Bild 'very famous picture'; 3) Tense and person markers on verbs. For example, in HCSG wir hatten ... ausgemacht 'we agreed on', - $t$ was counted as a past tense marker and $-n$ as a person marker. The prefixes and suffixes on the past participle forms of nonprefixed verbs were counted as two instances of synthetic marking, for example, HCSG gut geklappt 'worked well'. This is particularly relevant as the realization of circumfixes is not necessarily automatic (see, for example, PC wo hast du Duits gelern $\varnothing$ 'where did you learn German' or ich hab Ølernen Duits 'I learned German'). The 
suffix - $t$ in lexicalized participles was not counted because its verbal or adjectival status often remains unclear (for example, HCSG bestimmte Momente 'certain moments').

The comparison of the three types of varieties for the occurrence of these features of syntheticity shows the following token frequencies.

\begin{tabular}{|c|r|r|r|}
\hline Subcorpora (N=3 x 1000) & \multicolumn{1}{c|}{ LCL1G } & \multicolumn{1}{c|}{ HCSG } & \multicolumn{1}{c|}{ PC } \\
\hline 1 & 309 & 257 & 203 \\
\hline 2 & 291 & 219 & 250 \\
\hline 3 & 287 & 210 & 212 \\
\hline Average & $\mathbf{2 9 5 . 6 7}$ & $\mathbf{2 2 8 . 6 6}$ & $\mathbf{2 2 1 . 6 6}$ \\
\hline
\end{tabular}

Table 1. Syntheticity indices for the subcorpora.

Table 1 shows that $29.56 \%$ of all tokens in LCL1G, $22.86 \%$ of all tokens in HCSG, and $22.16 \%$ in PC are marked by bound grammatical morphemes. This data demonstrate that as a low-contact L1 variety, LCL1G has the largest synthetic complexity. There are considerably fewer synthetic morphological markers in HCSG and in PC. We found significant mean differences between LCL1G and HCSG ( $\mathrm{p}=0.009)$, and between LCL1G and PC ( $\mathrm{p}=0.006)$. The mean difference between HCSG and PC is minor and not statistically meaningful $(\mathrm{p}=0.703)$.

\subsection{Analyticity.}

In order to calculate the analyticity indices for the varieties, all function words were analyzed: determiners (definite, indefinite, possessive articles as in HCSG die normale Strafe 'the common sentence', einen Termin 'an appointment', mit ihrem Mann 'with her husband'), pronouns (for example, HCSG ich 'I', diese 'these', the reflexive pronoun sich '-self/selves' as in hat sich da drauf auch gefreut 'also looked forward to that'), coordinating (for example, HCSG und 'and', aber 'but') and subordinating conjunctions (for example, HCSG nachdem 'after', weil 'because'), the infinitive marker $z u$ 'to' (hat sich jetz auch entschieden nen qualifizierten entzug durchzuführen 'decided to do a qualified detoxification'), the auxiliaries haben 'to have' and sein 'to be' (as in HCSG ich hab ihn dann gefragt 'I then asked him' or PC ich bin in vieren-sestig bin ich nach Swakop gekommen 'in 64 I came to Swakop'), the copular verb sein 'to be', other auxiliaries such as werden 'to be' (for 
example, in PC was wird da umgewandelt in Gold 'what is being converted into gold'), modals (for example, HCSG dann müsst ma da grad $n$ termin ausmachen 'we would have to make an apointment' or brauchen 'to need', for example, HCSG sie bräuchte des nich nehmen 'she does not need to take this'), prepositions (for example, HCSG für 'for', mit 'with', nach 'after'), and negators (for example, HCSG kein 'no', nicht 'not') were analyzed. The following table shows the distribution of analytical morphological features in all varieties:

\begin{tabular}{|c|r|r|r|}
\hline Subcorpora (N=3 x 1000) & \multicolumn{1}{c|}{ LCL1G } & \multicolumn{1}{c|}{ HCSG } & \multicolumn{1}{c|}{ PC } \\
\hline 1 & 580 & 417 & 494 \\
\hline 2 & 562 & 468 & 486 \\
\hline 3 & 549 & 475 & 481 \\
\hline Average & $\mathbf{5 6 3 . 6 6}$ & $\mathbf{4 5 3 . 3 3}$ & $\mathbf{4 8 7}$ \\
\hline
\end{tabular}

Table 2. Analyticity indices for the subcorpora.

There are about twice as many analytical as synthetic markers in all these varieties (see table 1). LCL1G shows $56.35 \%$, HCSG $45.33 \%$ and PC $48.7 \%$ free grammatical morphemes of all tokens. Again, according to our hypotheses, LCL1G as a traditional low-contact L1 variety has by far the highest analyticity index. It differs significantly from HCSG ( $\mathrm{p}=$ $0.001)$ and from PC $(p=0.004)$. The mean difference between the two high-contact varieties, namely, HCSG and PC, is not statistically significant $(\mathrm{p}=0.094)$.

\subsection{Grammaticity.}

The grammaticity index was calculated based on the total number of all bound and free morphological markers, which adds up to the overall frequency of grammatical marking in all the varieties analyzed.

\begin{tabular}{|c|r|r|r|}
\hline Subcorpora (N=x 1000) & \multicolumn{1}{|c|}{ LCL1G } & \multicolumn{1}{|c|}{ HCSG } & \multicolumn{1}{|c|}{ PC } \\
\hline 1 & 889 & 674 & 697 \\
\hline 2 & 853 & 687 & 736 \\
\hline 3 & 836 & 685 & 693 \\
\hline Average & $\mathbf{8 5 9 . 3 3}$ & $\mathbf{6 8 2}$ & $\mathbf{7 0 8 . 6 6}$ \\
\hline
\end{tabular}

Table 3. Grammaticity indices for the subcorpora. 
The data in table 3 show relatively high indices for structural complexity in all three varieties. The traditional low-contact L1 variety LCL1G has the highest grammaticity index and differs significantly from both highcontact varieties $(\mathrm{p}=0.000)$; this was also the case with respect to syntheticity and analyticity. These results support our hypothesis, according to which high-contact varieties are less complex than low-contact varieties.

However, the frequency difference between HCSG and PC was again not significant $(\mathrm{p}=0.174)$. The reason for higher grammaticity indices for LCL1G can be illustrated, for instance, by past participle forms occurring in this variety. LCL1G has developed higher degrees of allomorphies in first and second parts of past participle circumfixes. On the one hand, the first part of LCL1G circumfixes can be realized as $g a$ - or ge-, for example, gavuort (HCSG geführt) 'have led' or gebolaibat (HCSG geblieben) 'have stayed'. On the other hand, the second part, even within the same verb, can be marked in different ways, for example, by -on or -en, as in kangon and gangen (gegangen) 'have gone'. In this sense, the higher grammaticity index of LCL1G in comparison to German-based pidgins and creoles has to do, among other things, with the fact that the second part of PC circumfixes is often represented by zero suffixes, as in wo hast du Duits gelern $\emptyset$ 'where did you learn German'. In contrast, LCL1G can be characterized not only by higher type variability of comparable suffixes but also by their high frequency.

\subsection{Irregularity.}

Measuring irregularity is an important part of testing our proposed hypotheses as defined by Trudgill (2001). We expect that simplification of the high-contact varieties due to adult second language acquisition would lead to regularization of the irregularities in the low-contact varieties of the same language. This in turn would result in an increase in transparency. In order to determine the degree of irregularity in all the varieties analyzed, all irregular (that is, marked and/or unproductive) markers in the corpora were identified and the mean value for their frequencies in the text was calculated. Inflectional plural markers on nouns as well as stem modifications of the plural noun forms (for example, HCSG bei allen Rundgängen 'during every tour', Bedürfnisse 'needs'), irregular verb forms with stem change (for example, HCSG aufgestanden 'got up', hielten 'held', musste 'had to', konnten 'could', 
ging 'went'), and suppletive verb and adjective forms (for example, HCSG gewesen 'have been', bin '(I) am', war 'was', besser 'better') were considered to be irregular. The suffix -en of the past participle verb forms is also included here (for example, HCSG gesessen 'have sat'). Our corpus analysis yielded the results in table 4 .

\begin{tabular}{|c|r|r|r|}
\hline Subcorpora (N=3 x 1000) & \multicolumn{1}{|c|}{ LCL1G } & \multicolumn{1}{|c|}{ HCSG } & \multicolumn{1}{|c|}{ PC } \\
\hline 1 & 235 & 153 & 109 \\
\hline 2 & 232 & 161 & 90 \\
\hline 3 & 208 & 129 & 130 \\
\hline Average & $\mathbf{2 2 5}$ & $\mathbf{1 4 7 . 6 6}$ & $\mathbf{1 0 9 . 6 6}$ \\
\hline
\end{tabular}

Table 4. Irregularity indices for the subcorpora.

Again, the frequency indices suggest a correlation between the type of variety and the degree of morphological transparency: As a low-contact L1 variety, LCL1G shows by far the highest proportion of irregular morphological markers, and PC the lowest. The high-contact varieties, that is, HCSG $(p=0.002)$ and PC $(p=0.000)$, differ significantly from LCL1G. The frequency difference between HCSG and PC is significant $(\mathrm{p}=$ 0.036). Figure 1 gives an overview of complexity indices for all the data.

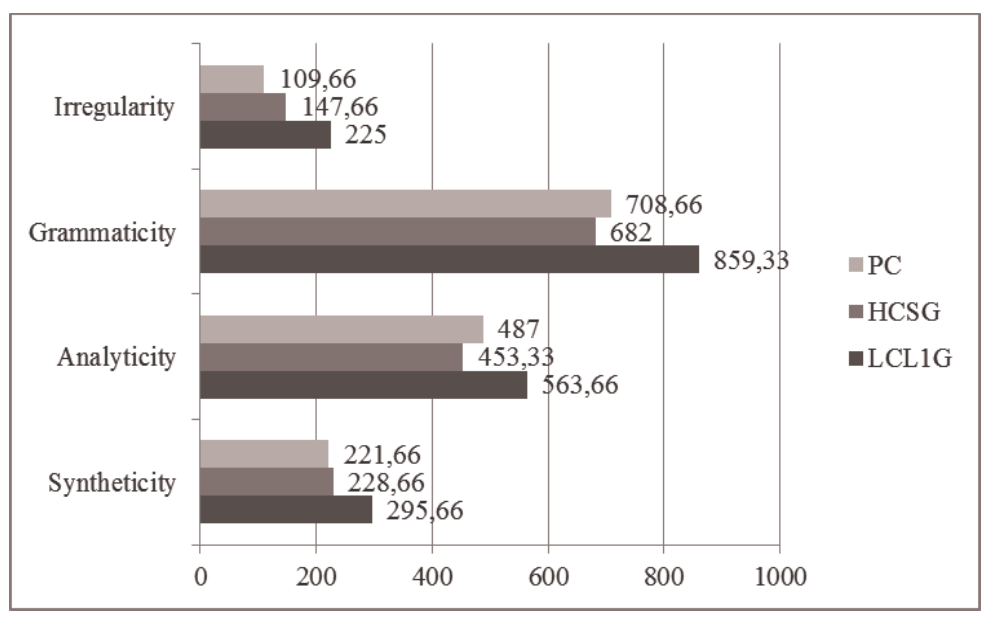

Figure 1. Overview of the complexity indices.

In all, the complexity indices presented in figure 1 suggest that lowcontact varieties such as Cimbrian (LCL1G) generally tend to be more 
complex than high-contact varieties such as pidgins and creoles (PC). These results seem to support our basic assumptions presented above in section 2. In what follows, we discuss these findings in further detail.

\subsection{The Correlation between the Factors/Indices.}

The remaining issue concerns the possible correlation between the complexity factors discussed above and the degree to which our data support results from previous research. It seems that to address this issue, one would have to answer the following questions:

(7) a. Is a higher degree of syntheticity accompanied by lower analyticity indices in these varieties? Is there a positive or negative correlation between syntheticity and analyticity that can be proved empirically?

b. Do low-contact L1 varieties show a higher degree of structural complexity and at the same time a higher degree of morphological irregularity (see Kortmann \& Szmrecsanyi 2012:17f)?

To answer the question in $7 \mathrm{a}$, we looked at the correlation between the syntheticity and the analyticity indices in all three varieties. As the analysis of the linear regression shows (see scatterplot in figure 2 below), there is a positive correlation between syntheticity and analyticity in all three varieties, that is, the higher the occurrence of overt synthetic morphological markers, the higher the proportion of analytical morphological structures $\left(\mathrm{R}=0.690, \mathrm{R}^{2}=0.476\right.$; ANOVA: $\mathrm{df}=1, \mathrm{~F}=6.362, \mathrm{p}=$ $0.04)$. This result indicates that there is no trade-off between syntheticity and analyticity.

As figure 3 (below) shows, the interplay between the factors grammaticity and transparency is similar, in that there is also a positive correlation between the quantitative complexity of morphological structures and the proportion of irregular morphological markers $(\mathrm{R}=0.829$, $\mathrm{R}^{2}=0.687$; ANOVA: $\mathrm{df}=1, \mathrm{~F}=15.388, \mathrm{p}=0.006$ ). 


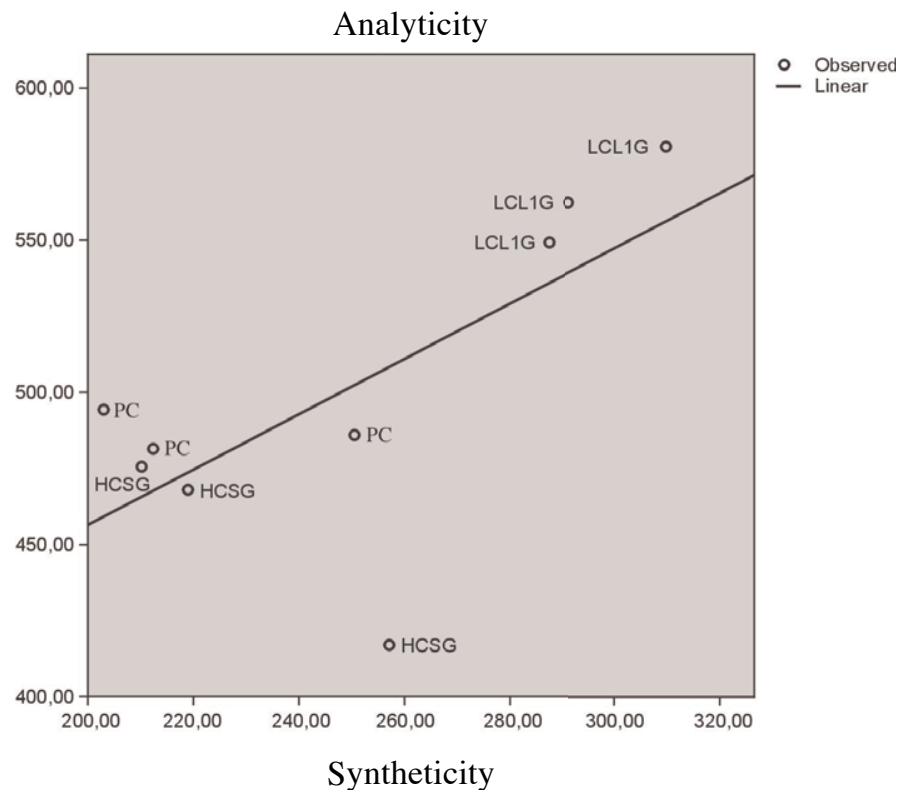

Figure 2. Interplay between analyticity and syntheticity.

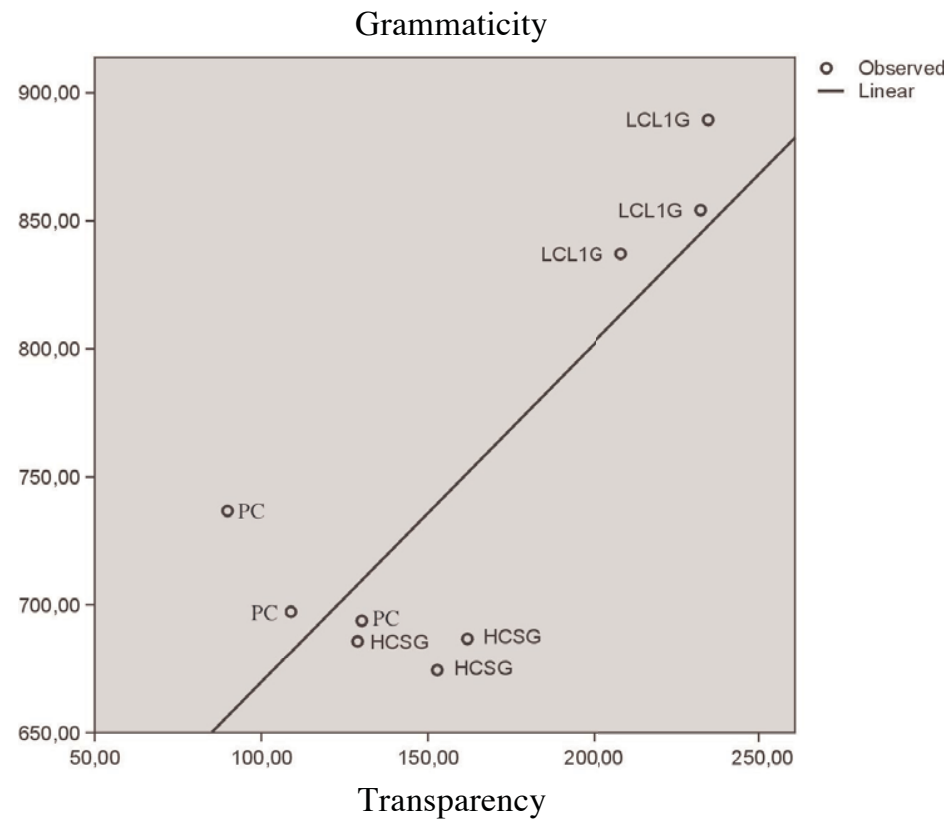

Figure 3. Interplay between grammaticity and transparency. 
Overall, the results indicate that there is no negative correlation between analytical and synthetic morphological markers, and lower syntheticity indices do not imply higher analyticity indices, and vice versa. These findings are consistent with the results presented in Kortmann \& Szmrecsanyi 2009:281. Moreover, the results show that low morphological transparency, that is, a higher degree of irregularity, is typical for morphosyntactically more complex varieties, such as traditional L1 varieties.

\section{Discussion.}

Related to our hypotheses (HYP1) and (HYP2), the main results of our study can be summarized as follows:

(8) Result 1: The quantitative analysis of all four factors shows significantly higher complexity indices for the low-contact L1 variety (LCL1G) than for the high-contact varieties (HCSG and PC).

Result 2: The high-contact L1 variety shows significantly higher complexity indices with regard to the irregularity compared to the analyzed high-contact L2 varieties. Regarding grammaticity, no significant difference was found between the two types of high-contact varieties.

The significant differences in complexity between the analyzed lowcontact variety on the one hand and the high-contact varieties on the other, as well as the significant differences in regularity/transparency between the high-contact L1 and L2 varieties support our hypotheses (HYP1) and (HYP2) in that there is a negative correlation between the intensity of the language contact and the degree of morphosyntactic complexity. However, the fact that the high-contact L1 and L2 varieties show no significant difference in grammaticity is striking and needs to be explained. As a result of contact-induced simplification due to adult second language acquisition, we would expect lower grammaticity indices for the L2 varieties. This paper cannot provide an empirically established explanation for this result. However, we propose that under certain assumptions, these findings can be explained. 
On the one hand, the language acquisition context, which is in some respects atypical, could contribute to the relatively high structural complexity of the high-contact L2 varieties (compared to prototypical pidgins and creoles). Unserdeutsch developed around the turn of the 20th century among speakers who had a high competence in HCSG through lessons in German at the missionary schools (see Volker 1991). The influence of this elaborated form of HCSG could have led to complexity being maintained to a certain extent. Black Namibian German developed in a similar way (see Deumert 2009:374ff): Some people in Namibia acquired German in their childhood at home and also learned German in the German missionary schools. Most adult natives, however, acquired German in their working environment. Besides, according to Deumert (2009:379ff), Black Namibian German was not only used as the lingua franca within the out-group communication, but also within in-group contexts, which is rather atypical of classic pidgins. As a result, Black Namibian German has developed more elaborated mesolectal and acrolectal varieties in addition to strongly simplified basilectal varieties. It is therefore questionable whether Black Namibian German can be unconditionally classified as a "classic" pidgin at all. Deumert (2009:406) states:

Certain contours would support one perception or interpretation, others the alternative. [...] Morphosyntactic reduction, reanalysis, and substrate-based innovations seemed to imply something akin to the notion of a pidgin language. Yet, substantive continuations of superstrate $[\ldots]$ features in lexicon and syntax as well as extensive inter- and intraspeaker variation did not easily fit this interpretation.

On the other hand, noticeable recent developments in HCSG are making this variety more and more similar to high-contact $\mathrm{L} 2$ varieties with regards to grammatical complexity. In particular, verbal and nominal inflectional morphology is being simplified through regularization of irregularities and reduction of morphological distinctions. For example, the regularization of irregular, so-called "strong" verbs, as in 3rd person singular past tense bestritt $\rightarrow$ bestreitete 'denied', rief $\rightarrow$ rufte 'called/shouted', lieh $\rightarrow$ leihte 'lent', buk $\rightarrow$ backte 'baked', leads to more transparent paradigms; the increase in regular plural markers for nouns (see Wegener 2007:39-42); the reduction of inflectional case markers, as in Hotel mit 120 Zimmer $\emptyset$ 'hotel with 120 rooms' partly due to the increasing loss of the inflectional class of weak masculine and 
neuter nouns (Stipendium für jeden Student $\varnothing$ 'scholarship for every student'); the replacement of synthetic comparative forms of adjectives with analytical ones (aufgeregter $\rightarrow$ mehr aufgeregt 'more excited'), the use of uninflected attributive adjectives (lecker $\varnothing$ Eis essen 'eat delicious ice cream'), etc.

Wegener (2007) and Hinrichs $(2004,2009)$ have already discussed all these and other developments as possible L2 effects (several examples were taken from these sources). The fact that these developments correlate with typical features of both learner varieties and creole languages is notable. The influence of asymmetric and deficient multilingualism, especially when simplified (indigenized and nonindigenized) L2 varieties are involved, has to be taken into account. Such L2 varieties might influence the L1 varieties of German, especially HCSG, through linguistic accommodation in face-to-face interaction and conscious or unconscious foreigner talk (see Thomason \& Kaufman 1988:177, Hinrichs 2009:53).

At the same time, we would like to emphasize that the hypothesized correlation between language contact and linguistic complexity should be regarded as a contributing factor and not as a monocausal explanation. It goes without saying that language change can lead to both complexification and simplification of a language variety. Kortmann \& Szmrecsanyi (2009:283) claim:

[W]e should not be surprised to see that simplification processes have also taken place in low-contact L1 varieties over time, just as complexification processes have taken place in the other three types of varieties; the main difference lies in which type of processes, simplification or complexification, outweighs the other in the relevant variety or variety type.

In this sense, the hypothesis only states that more simplifications are expected in high-contact varieties than in low-contact varieties as a result of language contact (that is, as a consequence of adult second language learning).

However, there are, of course, several other factors that can yield a different picture, for example, analogy, cliticization, etc. Despite the above-mentioned simplifications, there are also complexifications as, for instance, in HCSG. Complexification can occur, for instance, as a result of phonologically motivated cliticizations, which can lead to a decrease 
in morphological transparency, as in vom 'of' < von 'of' + dem 'the.DAT'. It can also lead to a change in inflectional class (from weak to strong conjugation), as in the case of the verb winken 'to wave', where the older weak participle gewinkt is replaced more and more frequently by the irregular form gewunken. This appears to be a case of analogy, whereby the more recent weak verb follows the pattern of frequently used, still existing strong verbs (see binden-gebunden 'to tie-tied', trinken-getrunken 'to drink-drunk', sinken-gesunken 'to sink-sunk', etc.).

Although there are other developments that can be interpreted as simplifications, they are presumably not contact-induced but phonologically motivated. These are morphologically relevant sound deletions in unstressed word-final positions, especially the deletion of the - $e$ (schwa) in the 1st person singular (ich hab Ø 'I have'/mach Ø 'I make', etc.) or the deletion of the inflectional morpheme $-t$ in the $3 \mathrm{rd}$ person singular in word-final consonant clusters (er/sie/es brauch $\emptyset$ 'he/she/it needs'; see Girnth 2000, Maitz \& Tronka 2009).

In this article, we have focused on the role of a single factor, namely, language contact. The results of our analysis, just like those of many of the empirical analyses we have referred to, seem to indicate a correlation between language contact (due to adult second language acquisition) and linguistic complexity. However, future research would have to clarify 1) to what extent and under what circumstances language contact may cause structural simplification, and 2) under what circumstances and to what extent other internal and external factors may influence the complexity of a language.

With regard to the empirical examination of the role of language contact, three methodological approaches seem practicable. First, one can undertake a diachronic analysis of a particular variety by identifying and comparing its structural complexity over two periods with a different degree of intensity of language contact (for example, Norwegian before and after the Hanseatic period). Second, one is likely to obtain important empirical evidence by comparing multiple varieties of the same language, which are affected to different degrees by language contact (as in this paper). Third, one can compare distinct yet genetically closely related languages (for example, Germanic languages) affected to different degrees by language contact. 
The third approach, namely, a comparative analysis of German and other Germanic languages, seems especially promising since it would be expected to reveal further social factors that affect linguistic complexity. It is well known that German has rich inflection compared to other Germanic languages. Only Icelandic and Faroese have a more complex inflectional system (see McWhorter 2004, Schmid 2009:183). The noticeable morphosyntactic complexity of Icelandic and Faroese is consistent with the hypotheses in 4 (Trudgill, 2011a:100-104): Both are low-contact languages; they are geographically isolated and spoken by a relatively small group of people, and as such are not likely to undergo extensive contact-induced structural simplification. In contrast, we have claimed that HCSG has to be regarded as a high-contact variety because of its traditional function as a lingua franca, and also because of the high volume of labor migration in the recent past. If this is really the case, the question posed by Campbell \& Poser (2008:362) seems to be legitimate: If HCSG is a high-contact variety, how would one explain why German does not show extensive structural simplification similar to the mainland Scandinavian languages?

According to Trudgill (2011a:56-60), this is because the proportion of non-native speakers has been too low for significant contact-induced simplification. However, we think that for German, the demographic situation is only one of the factors responsible for the maintenance of relatively high structural complexity. In accordance with Hinrichs 2004, 2009 and Wegener 2007, we have tried to demonstrate that HCSG shows more and more contact-induced simplification effects. When discussing these effects, the multiethnicity and the multilingualism of these speech communities, and the millions of adult L2 learners of German have to be taken into account, as the interaction among speakers of L1 and L2 varieties gives rise to linguistic accommodation (see Trudgill 1986).

In our view, another major factor that prevents contact-induced simplification in German is the attitude of the German speech community toward prescriptive linguistic norms. This factor was pointed out by, for example, Harnish (2004:527), but so far it has not received much attention in typological research. The German speech community is highly normative compared to other European language communities (see Durrell 1999, Elspaß \& Maitz 2012) and in this respect is more similar to the Icelandic or Faroese speech community than to the Dutch or Norwegian community. The strict adherence to linguistic norms has been 
characteristic of German at least since the 17th century, at the early stages of formal codification in the late humanistic-Baroque period; it increased in the 19th century, when the standard language became a social symbol under the influence of the educated middle classes (see Mattheier 1991). Already in the Early Modern period (from the 17th century on), this norm was modeled after Latin and the ideal of an inflectional language. This normative attitude even caused a restitution of inflectional morphemes (for example, $-e$ as a plural or dative marker on nouns), which had already disappeared in spoken language, under the influence of grammarians and professional scribes, following the Protestant Reformation. As can be seen, strict adherence to the linguistic norm had a noticeable retarding effect and greatly contributed to the preservation of morphosyntactic complexity.

The role of linguistic ideology and attitudes toward the norm within a speech community also becomes apparent when one examines the divergent development of German and Yiddish. Timm (1986:10-14) shows that Yiddish, especially Eastern Yiddish, whose development was not influenced by the Latin-oriented prescriptive rules for German from the 17th to 19th centuries, underwent significant structural simplification, which was prevented or retarded by rigid linguistic norms in German. Such processes of simplification in Yiddish include regularization of verbal inflection, such as the elimination of stem vowel alternation, as in haltn-du haltst (compare HCSG halten-du hältst 'to hold') or the elimination of all alternations in verbs, as in geben 'to give', darfn 'to be allowed' (compare HCSG geben-du gibst, dürfen-du darfst), etc.; another example of simplification is the decrease in redundancy due to loss of morphological categories and morphological markers in both nominal and verbal inflection (for example, inflection of definite articles as well as possessive and reflexive pronouns, case marking on nouns, weak/strong distinction in adjectives, etc.; see also Kiefer 2004:32623264).

In conclusion, our data support the view expressed by von Polenz (1994:254):

So liegt es nahe anzunehmen, dass die deutsche Sprache als Standardsprache heute sicher ähnlich flexionsarm, also mehr nach dem analytischen Sprachbau wäre wie etwa das Niederländische oder Englische, wenn die deutsche Sprachentwicklung in der Zeit des bildungsbürgerlich kultivierten deutschen Absolutismus nicht so stark 
schreibsprachlich, akademisch, lateinorientiert, flexionsfreundlich und sprachideologisch gesteuert verlaufen wäre. In die sprachtypologische Entwicklung ist retardierend eingegriffen worden [...].

So it is a natural assumption that German as a standard language today would have definitely been less inflectional and more analytic - similar to Dutch and English-if its development during the German Absolutism, cultivated by an educated middle class, had not been so strongly governed by written language, academia, focus on Latin, a penchant for inflection, and language ideology. The typological development has been slowed down by this influence.

\section{APPENDIX}

Samples from the Corpus of Texts Analyzed

HCSG (FOLK_E_00114_SE_01_T_01):

Ich hab dann mit dem Sohn vereinbart, dass er beziehungsweise ich hab ihn dann gefragt, wie dieser Bekannte_pp im Moment dazu steht. Er hat dann gesagt, na ja, im Moment möcht er eigentlich so $\mathrm{n}$ bisschen den Kontakt mal meiden, um da so $\mathrm{n}$ bisschen wieder runderzufahren des ganze, weil ihm des auch $\mathrm{n}$ bisschen viel war. Er, dieser Bekannte_pp war auch derjenige gewesen, wo des so alles die ganze Aufnahme initiiert hat dem Sohn gegenüber, den Sohn angerufen un hat gesagt, hallo da stimmt irgendwas nich, kümmer dich mal ne, okay, ja also wie gesagt, wir sin dann so verblieben, dass er jetz Anfang nächster Woche anrufen sollte, oder wollte, besser gesagt von sich aus, aber jetzt wie gesagt, habt er ja eben mitgekriecht, jetz hat er selber angerufen, dann doch sie hat jetzt grad mit dem Sohn telefoniert, eben, war da doch recht aufbrausend noch ihm gegenüber, sehr vorwurfsvoll, auch insgesamt hat ihm ganz viele Sachen irgenwie gesagt, die er jetz erledigen muss, Geld besorgen, unterlagen besorgen, et cetera, gut, gestern war es dann so, nachdem des dann mit dem Telefonat alles geklärt war, is sie dann runtergekommen, war recht ruhig insgesamt gewesen, war auch gut führbar auf station

Kitche Duits/Namibian Black German (see Deumert 2003:598-599, 603):

Mesolectal speaker: wegen die Anna und dann .. alter zeiten geschichte .. und dann hat der lange jahre und dann hat er geheiratet mit 
diese kaffer frau, Anna, ja, geheiratet un dann hat er dann diese Heini und der Gustav und der Paul, war die kleinste, die Paul und dann hat er die Paulina und Emma und Maria, soviele Kinder hat der gekrieg un, ja, ja, Gustav hab ich schon gesagt, ja, hat der gekrieg, un die sind alle Maletzkis und der hat auch gesagt, da is mein Kinder, diese Leute haben mich versorgt und kein, mein famili nix, und das is mein famili und ich heiratet mit diese Frau und ich bleib mit diese frau und in die neue zeit mit diese Afrikaner, ne da wollen die doch mein opa und diese opa wegschicken, viele Deutsche in Rehoboth viele ham die, ham die weg von die frauen, zurück, zurück, das muss zurück

Basilectal speaker: eine mann, ich muss probieren, eine mann hat so viel kinders gehabt, nur die mädchens, so und die mann hat eine tag gesag: komm kinders- und almal alle seid hier gekomm stehn toe frag die vater- ei, lief? lieb- alles gefra: hast du mir lieben? nein, mit zucker hat eine gesagt, lieb ich meine vater, so die sind gute mädchens und hier hat gesag: ich bin lieb meine Vater genau wie die sout, salz och, hat die mann jetzt woes gewern en gesag: salz! nehm diese kind, mach mal tot da im .. die junge hat gekomm en genehmen un der hat geloof mit da bei die woestyn

Unserdeutsch/Rabaul Creole German (Rumpelstiltskin, http://www.unikoeln.de/gbs/):

Der dritte Tag kam und der Mensch wo geht durch de ganze Land sagen nachher: „Nur ein Name i konnte ni finden, ein neue Name.“ Und kein andere Name i konnte ni finden. I geht durch alle Busch, ueber alle ganz grosse Huegel und neben ein ganz kleine Haus de Haus war verbrannt von Feuer, und unter Feuer ein ganz komische kleine Mensch war am tanzen. Und er war am springen und springen und mit ein Bein und er war am schreien: „Heute ich wird backen, morgen I braeue, und der andere Tag I wird holen der Kind (?kind). Niemand weiss ... oh niemand weiss von das mein Name is 'Rumpelstiltskin'.“

\section{LCL1G (see Schweizer 1939:38-40):}

a jaar a mann is kchen aaber pa bege nader eits un is kangon ga bearn tsu vorkchofan a par ouksan. aber na'm' bege hatar vuntat tswoa manne, boda saubarn in bekch un die hen kchout: „geastodu tse vorkcho'vose d ouksan?" kchouts: ,ja, i vorkcho'ffose.“ „sainsa taur.“ kchoun d'ander. kchouts: ,i boass nicht, perke'ss ist a bail, bo i nicht ge ga vearn." 
da hensesi gelaat un iss ist gangen ga vearn un hat vorkchofft $d$ ouksan. dop' iss gangen au pa bege nadar eitsch tse gien huo, ha pidar vuntat die poade, bo hen gasaubert in bekch, kchousa: „hasto gafangat hupisch, sainsa gabest taur?" das ander kchats, shet gafangat hupisch: „i hete hicht gamot vangen sóuval.“ die bo arbotan an bekch, hense galoutset aa, oas pitam ander un hen gasecht, $\mathrm{k}^{\prime}$ ata is nimon, boda setse, henseme get in pada'ilj hintan po ruke un heme galoon iss gelt un hense gavangat, gaborst ab'in eitsch.

\section{REFERENCES}

Bidese, Ermenegildo. 2005. Die Zimbern und ihre Sprache: Geographische, historische und sprachwissenschaftlich relevante Aspekte. Das Zimbrische zwischen Germanisch und Romanisch, ed. by Ermenegildo Bidese, James R. Dow, \& Thomas Stolz, 3-42. Bochum: Brockmeyer.

Braunmüller, Kurt. 2004. Niederdeutsch und Hochdeutsch im Kontakt mit den skandinavischen Sprachen. Eine Übersicht. Deutsch im Kontakt mit germanischen Sprachen, ed. by Horst Haider Munske, 1-30. Tübingen: Niemeyer.

Campbell, Lyle, \& William Poser. 2008. Language classification: History and method. Cambridge: Cambridge University Press.

Dahl, Östen. 2004. The growth and maintenance of linguistic complexity. Amsterdam: John Benjamins.

Dammel, Antje, \& Sebastian Kürschner. 2008. Complexity in nominal plural allomorphy. A contrastive survey of ten Germanic languages. Miestamo, Sinnemäki, \& Karlsson 2008, 243-262.

Deumert, Ana. 2003. Markedness and salience in language contact and secondlanguage acquisition: Evidence from a non-canonical contact language. Language Sciences 25. 561-613.

Deumert, Ana. 2009. Namibian Kiche Duits: The making (and decline) of a Neo-African language. Journal of Germanic Linguistics 21.349-417.

Durrell, Martin. 1999. Standardsprache in England und Deutschland. Zeitschrift für Germanistische Linguistik 27. 285-308.

Elspaß, Stephan, \& Péter Maitz. 2012. New language norm authorities in Germany: Ideological roots and social consequences. Codification, canons, and curricula: Prescription and description in language and literature, ed. by Ulrich Busse, Ulrich, Ralf Schneider, \& Anne Schröder, 171-184. Bielefeld: Aisthesis.

Fiehler, Reinhard. 2009. Gesprochene Sprache. Duden. Die Grammatik, $1165-$ 1244. Mannheim: Dudenverlag. 
Girnth, Heiko. 2000. Untersuchungen zur Theorie der Grammatikalisierung am Beispiel des Westmitteldeutschen. Tübingen: Niemeyer.

Greenberg, Joseph H. 1960. A quantitative approach to the morphological typology of language. International Journal of American Linguistics 26. 178194.

Harnisch, Rüdiger. 2004. Morphologie. Sociolinguistics: An international handbook of the science of language and society, ed. by Ulrich Ammon, Norbert Dittmar, Klaus J. Mattheier, \& Peter Trudgill, 522-530. Berlin: De Gruyter.

Hinrichs, Uwe. 2004. Kreolisierungstendenzen im Deutschen? Einige Bemerkungen. Muttersprache 114. 348-357.

Hinrichs, Uwe. 2009. Sprachwandel oder Sprachverfall? Zur aktuellen Forschungssituation im Deutschen. Muttersprache 119.47-57.

Hockett, Charles F. 1958. A course in modern linguistics. New York, NY: Macmillan.

Jahr, Ernst Håkon. 2001. Historical sociolinguistics: The role of Low German language contact in the Scandinavian typological split of the late Middle Ages. Lingua Posnaniensis 43. 95-104.

Kiefer, Ulrike. 2004. Jiddisch/Deutsch. Sprachgeschichte. Ein Handbuch zur Geschichte der deutschen Sprache und ihrer Erforschung, ed. by Werner Besch, Anne Betten, Oskar Reichmann, \& Stefan Sonderegger, 3260-3268. Berlin: De Gruyter.

Kolmer, Agnes. 2010. Kontaktbedingte Veränderung der Hilfsverbrektion im Cimbro. Ergebnisse einer Pilotstudie. Strategien der Integration und Isolation nicht-nativer Einheiten und Strukturen, ed. by Carmen Scherer, \& Anke Holler, 143-164. Berlin: De Gruyter.

Kortmann, Bernd, \& Benedikt Szmrecsanyi. 2004. Global synopsis: Morphological and syntactic variation in English. A handbook of varieties of English, vol. 2, ed. by Edgar W. Schneider, Kate Burridge, Bernd Kortmann, Rajend Mesthrie, \& Clive Upton, 1142-1202. Berlin: De Gruyter.

Kortmann, Bernd, \& Benedikt Szmrecsanyi. 2009. World Englishes between simplification and complexification. World Englishes: Problemsproperties - prospects, ed. by Lucia Siebers, \& Thomas Hoffmann, 265-285. Amsterdam: Benjamins.

Kortmann, Bernd, \& Benedikt Szmrecsanyi. 2012. Language complexity: Second language acquisition, indigenization, contact. Berlin: De Gruyter.

Kusters, Wouter. 2003. Linguistic complexity: The influence of social change on verbal inflection. Utrecht, The Netherlands: Utrecht University dissertation.

Kusters, Wouter. 2008. Complexity in linguistic theory, language learning and language change. Miestamo, Sinnemäki, \& Karlsson 2008, 3-22.

Lenneberg, Eric. 1967. Biological foundations of language. New York, NY: Wiley. 
Maitz, Péter, \& Krisztián Tronka. 2009. brauchen-Phonologische Aspekte der Auxiliarisierung. Zeitschrift für Dialektologie und Linguistik 76. 189-202.

Mattheier, Klaus J. 1991. Standardsprache als Sozialsymbol. Über kommunikative Folgen gesellschaftlichen Wandels. Das 19. Jahrhundert. Sprachgeschichtliche Wurzeln des heutigen Deutsch, ed. by Rainer Wimmer, 41-72. Berlin: De Gruyter.

McWhorter, John H. 2004. What happened to English? Focus on Germanic typology, ed. by Werner Abraham, 19-60. Berlin: Akademie Verlag.

McWhorter, John H. 2011. Linguistic simplicity and complexity: Why do languages undress? Berlin: De Gruyter.

Miestamo, Matti. 2008. Grammatical complexity in a cross-linguistic perspective. Miestamo, Sinnemäki, \& Karlsson 2008, 23-41.

Miestamo, Matti, Kaius Sinnemäki, \& Fred Karlsson (eds.). 2008. Language complexity: Typology, contact, change. Amsterdam: John Benjamins.

Milroy, James. 1992. Middle English dialectology. The history of the English language II: 1066-1476, ed. by Norman Blake, 156-206. Cambridge: Cambridge University Press.

Mühlhäusler, Peter. 2001. Die deutsche Sprache im Pazifik. Die deutsche Südsee 1884-1914. Ein Handbuch, ed. by Hermann J. Hiery, 239-260. Paderborn: Schöningh.

Polenz, Peter von. 1994. Deutsche Sprachgeschichte vom Spätmittelalter bis zur Gegenwart, vol. 2: 17. und 18. Jahrhundert. Berlin: De Gruyter.

Rowley, Anthony R. 1996. Die Sprachinseln der Fersentaler und Zimbern. Handbuch der mitteleuropäischen Sprachminderheiten, ed. by Robert Hinderling, Ludwig M. Eichinger, \& Rüdiger Harnisch, 265-285. Tübingen: Narr.

Sampson, Geoffrey. 2009. A linguistic axiom challenged. Language complexity as an evolving variable. Sampson, Gil, \& Trudgill 2009, 1-18.

Sampson, Geoffrey, David Gil, \& Peter Trudgill (eds.). 2009. Language Complexity as an Evolving Variable. Oxford: Oxford University Press.

Schmid, Hans Ulrich. 2009. Einführung in die deutsche Sprachgeschichte. Stuttgart: Metzler.

Schweizer, Bruno. 1939. Zimbrische Sprachreste. Teil 1: Texte aus Giazza (Dreizehn Gemeinden ob Verona). Nach dem Volksmunde aufgenommen und mit hochdeutscher Übersetzung. Halle: Niemeyer.

Schweizer, Bruno. 2008. Zimbrische Gesamtgrammatik. Vergleichende Darstellung der zimbrischen Dialekte, ed. by James R. Dow. Stuttgart: Steiner.

Shosted, Ryan K. 2006. Correlating complexity: A typological approach. Linguistic Typology 10. 1-40.

Siegel, Jeff. 2012. Accounting for analicity in creoles. Kortmann \& Szmrecsanyi 2012, 35-61. 
Sinnemäki, Kaius. 2009. Complexity in core argument marking and population size. Sampson, David, \& Trudgill 2009, 126-140.

Szmrecsanyi, Benedikt, \& Bernd Kortmann. 2012. Introduction: Linguistic complexity - Second Language Acquisition, indigenization, contact. Kortmann, \& Szmrecsanyi 2012, 6-34.

Thomason, Sarah Grey, \& Terrence Kaufman. 1988. Language contact, creolization, and genetic linguistics. Berkeley: University of California Press.

Timm, Erika. 1986. Das Jiddische als Kontrastsprache bei der Erforschung des Frühneuhochdeutschen. Zeitschrift für Germanistische Linguistik 14. 1-22.

Trudgill, Peter. 1986. Dialects in contact. Oxford: Blackwell.

Trudgill, Peter. 2001. Contact and simplification: Historical baggage and directionality in linguistic change. Linguistic Typology 5. 371-374.

Trudgill, Peter. 2009. Sociolinguistic typology and complexification. Sampson, Gil, \& Trudgill 2009, 98-109.

Trudgill, Peter. 2010. Contact and sociolinguistic typology. The handbook of language contact, ed. by Raymond Hickey, 299-319. Oxford: WileyBlackwell.

Trudgill, Peter. 2011a. Sociolinguistic typology: Social determinants of linguistic complexity. Oxford: Oxford University Press.

Trudgill, Peter. 2011b. Social structure, language contact and language change. The SAGE handbook of sociolinguistics, ed. by Ruth Wodak, Barbara Johnstone, \& Paul Kerswill, 236-248. Los Angeles: SAGE.

Volker, Craig. 1989. Rabaul Creol German syntax. Working Papers in Linguistics 21. 153-189. Honolulu: University of Havaii at Manoa, Department of Linguistics.

Volker, Craig. 1991. The birth and decline of Rabaul Creole German. Language and Linguistics in Melanesia 22. 143-156.

Wegener, Heide. 2007. Entwicklungen im heutigen Deutsch-Wird Deutsch einfacher? Deutsche Sprache 35. 35-62.

Péter Maitz

Department of German Linguistics

Faculty of Philology and History

University of Augsburg

Universitätsstraße 10

D-86159 Augsburg

Germany

[peter.maitz@phil.uni-augsburg.de] 
Attila Németh

Department of German Linguistics

Faculty of Modern Philology and Social Sciences

University of Pannonia

Füredi u. 2

H-8200 Veszprém

Hungary

[nemeth.attila@btk.uni-pannon.hu] 